\title{
Serologic screening and infectious diseases consultation in renal transplant candidates for measles, mumps, rubella and varicella
}

\author{
ZEYNEP IDIL SECKIN ${ }^{1}$, CLAUDIA R. LIBERTIN ${ }^{2}$, LISA M. BRUMBLE ${ }^{2}$ \\ ${ }^{1}$ Department of Internal Medicine, Mayo Clinic, Jacksonville, Florida, USA \\ ${ }^{2}$ Division of Infectious Diseases, Mayo Clinic, Jacksonville, Florida, USA
}

\begin{abstract}
Background. Renal transplant recipients are at increased risk for developing complications of vaccine-preventable diseases. They benefit from a comprehensive pre-transplant evaluation when they might safely receive live vaccines. The primary aim of our study was to investigate the number of renal transplant recipients who were evaluated for serologic status against measles, mumps, rubella (MMR), and varicella. Secondarily, we investigated if pre-transplant Infectious Diseases consultation (IDC) improved vaccination rates.

Methods. We retrospectively analyzed 282 kidney-alone and kidney-plus adult transplant recipients who were born in or after 1957. Patients were evaluated at Mayo Clinic, Florida Transplant Center between January 2015 and December 2017. Serologic status evaluation and vaccination rates were compared in two groups created based on IDC and no ID consultation (NIDC).

Results. $235(83 \%)$ of a total 282 patients received an IDC pre-transplantation. Varicella IgG levels were screened in all 235 IDC candidates. Among the IDC patients, mumps, measles and rubella $\mathrm{IgG}$ serologies were performed in 7 (3\%), $143(61 \%)$ and 144 (61\%), respectively. Among 44 patients seronegative for any of MMR, $24(55 \%)$ were vaccinated. Ten $(66 \%)$ of 15 varicella seronegative patients were vaccinated. Zostavax was not given to $18 \%$ of IDC patients. Zostavax and MMR were administered more frequently in the IDC group compared to NIDC $(p<.001$ and $p=0.0016$, respectively).

Conclusion. Although the majority of patients had IDC, the screening rate for MMR serologies was lower than varicella. A protocol-driven serologic screening similar to the one for VZV is required for MMR. Pre-transplant IDC increases vaccination rates.
\end{abstract}

Key words: infectious disease consultation, serologic screening, kidney transplantation, MMR, varicella.

\section{INTRODUCTION}

The number of transplants performed in the US increases yearly. From 2018 to 2019, it increased $8.7 \%$ [1]. In 2018, 21,167 kidney-alone and 836 kidney-plus at least one additional organ transplants were performed, representing a record number of renal transplants [2]. Furthermore, the introduction of effective immunosuppression has led to increased rates of both patient and graft survival [3]. However, immunosuppression is also associated with increased rates of infection $[4,5]$. Thus transplant candidates should undergo a thorough evaluation prior to undergoing transplantation. This IDC should include assessing immune responses and vaccination against diseases associated with high morbidity and mortality. Live attenuated vaccines such as MMR and varicella are not given after transplantation and are recommended to be given pre-transplantation $[3,6,7]$ provided the individual is not already immunosuppressed. There are emerging data on the safety of administering these vaccines (MMR and varicella) in pediatric post-transplant recipients [8]. Infectious Diseases consultation (IDC) with the assessment of immunity to MMR and varicella and administration of vaccines depending on serologic status are life-saving measures to decrease morbidity and mortality posttransplantation. The primary aim of our study was to investigate the number of renal transplant recipients who were evaluated for their immune status against measles, mumps, rubella (MMR), and varicella (VZV) and to determine if pre-transplant IDC improved vaccination rates.

\section{MATERIAL AND METHODS}

Our study was approved by the Mayo Clinic Institutional Review Board. We retrospectively analyzed 282 kidney-alone and kidney-plus at least one additional organ adult transplant recipients who were born in or after 1957. Patients were evaluated at Mayo Clinic, Florida, Transplant Center between January 2015 and December 2017. Pregnant patients and patients with positive HIV serology were excluded. Parameters collected from electronic medical records 
included: sex, birth year, transplantation year, IDC any time before transplantation, immunocompromised state due to therapy, prednisone $>10 \mathrm{mg} /$ day, antibody screening tests and results for MMR and varicella as well as if seronegative, MMR and Varicella/Zostavax vaccines were given before transplantation or not and history of any previous MMR and/or varicella infection. Comparisons of immunizations rates for those seen and not seen in IDC (NIDC) were made.

The JMP version 14.1 software was used for statistical analysis. Data were summarized by descriptive statistic results as numbers and percentages. Fisher's Exact test was used to compare serology status evaluation and vaccination rates in IDC and NIDC groups. The alpha was set at 0.05.

\section{RESULTS}

\section{Baseline characteristics}

Of the total 282 patients transplanted, 262 (93\%) were kidney, $13(5 \%)$ were kidney-pancreas, $6(2 \%)$ were kidney-liver, and $1(\% 0.3)$ was kidneyheart. Among all, 176 (62\%) patients were male. The age range was 20 to 60 years with a median age of transplantation at 46 years [Interquartile range (IQR) of 36-53]. Two hundred and thirtyfive $(83 \%)$ patients underwent IDC. Forty-two
(15\%) patients were immunocompromised before transplantation; among those, $18(43 \%)$ were taking prednisolone $>10 \mathrm{mg} /$ day.

\section{Serology status}

Of all 282 patients, serology status for mumps, measles, rubella and varicella were evaluated for 10 (4\%), $167(59 \%), 169(60 \%)$ and $282(100 \%)$ patients, respectively. Among those who were evaluated, mumps, measles, rubella, and varicella IgG were positive for $8(80 \%), 132(79 \%), 150$ (89\%) and 265 (94\%) patients, respectively. Among 235 IDC patients, serology status for mumps, measles, rubella and varicella was evaluated for 7 (3\%), 143 (61\%), $144(61 \%)$ and $235(100 \%)$ patients, respectively. Of 7 mumps serologies performed, 6 $(3 \%)$ patients were IgG positive and one $(0.4 \%)$ was negative. Of 143 measles serologies performed, $111(47 \%)$ patients were positive and $32(14 \%)$ were negative. Of 144 rubella serology performed $129(55 \%)$ patients were positive and $15(6 \%)$ were negative. Of 235 varicella serology performed patients, $221(94 \%)$ patients were positive and $14(6 \%)$ were negative (Table 1). IgG levels were considered protective if titers were as follows: measles $\operatorname{IgG} \geq$ $1.1 \mathrm{AI}$, mumps $\mathrm{IgG} \geq 1.1 \mathrm{AI}$, rubella $\mathrm{IgG} \geq 1.0 \mathrm{AI}$ and varicella $\operatorname{IgG} \geq 1.1 \mathrm{AI}$.

Table 1

Immunity status of patients

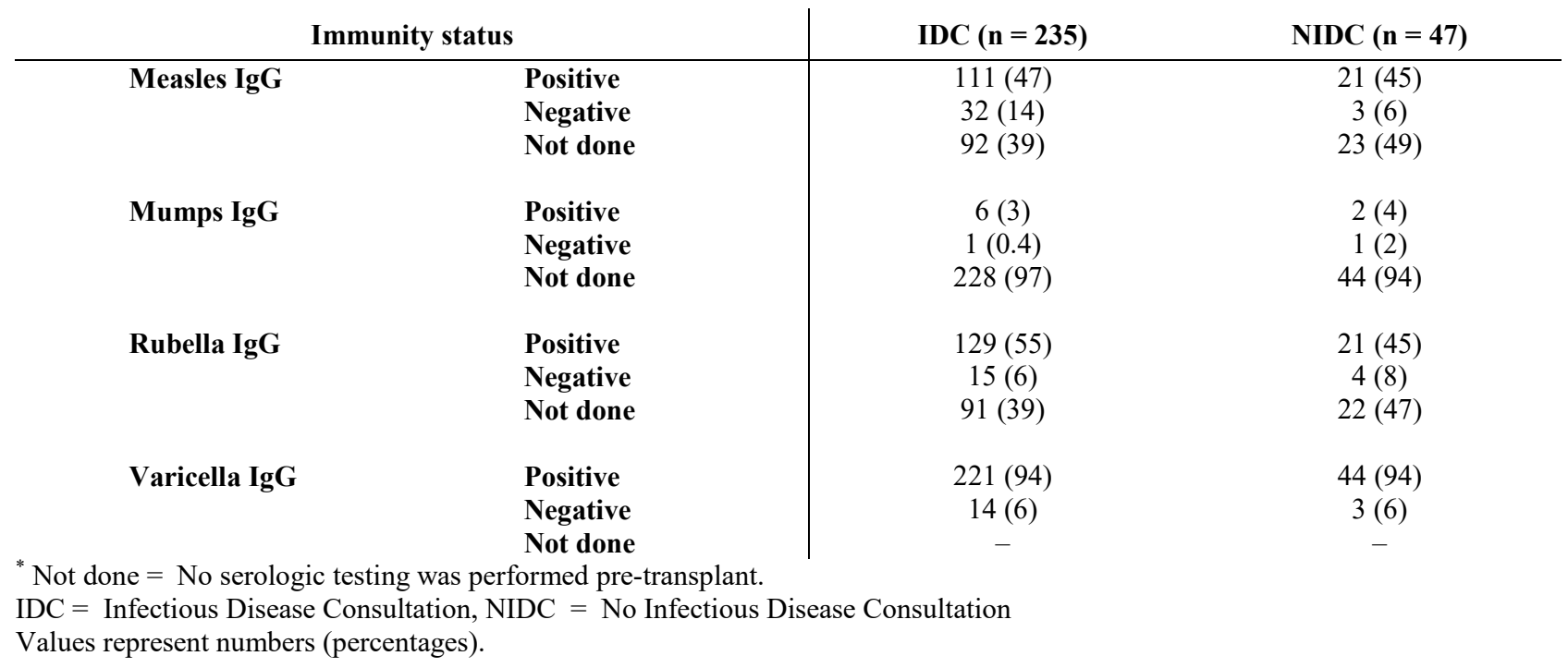

\section{Disease and vaccine history}

Patients who had IDC were asked about the history of previous mumps, measles, rubella, and varicella infection. Two patients reported mumps,
4 reported measles, 1 reported rubella, and 33 reported varicella. The remaining patients were not able to recall any history of the previous infection. The remaining 242 patients either could not recall any history of these viral infections or did not know. 
Forty-four patients who had negative $\operatorname{IgG}$ status for any of mumps, measles, and rubella were considered for MMR vaccine administration. Among those, 24 (55\%) received the vaccine; however, 20 (45\%) did not. Of the 20 patients not vaccinated, 7 had NIDC and 13 had IDC. MMR vaccines were ordered at time 0 and 4 weeks later. Fifteen patients were seronegative for varicella. Among those, 10 patients $(66 \%)$ received the vaccine; however, $5(33 \%)$ patients did not. Of these 5 patients, 2 had NIDC and 3 had IDC. All vaccinated patients were IDC. Varicella vaccines were ordered at time 0 and 4 weeks later. Unvaccinated IDC patients and the reason why they did not receive vaccines are demonstrated in the flowchart in Figure 1.

Of all 282 patients, 68 (24\%) patients received Zostavax; 214 (76\%) did not. All 235 IDC patients were evaluated for the need for Zostavax administration.
Sixty-seven patients $(28 \%)$ received the vaccine; however, 168 patients did not (72\%). Among those who did not receive Zostavax, 94 (56\%) patients were younger than 50 years, $36(21 \%)$ patients were immunocompromised, and $8(5 \%)$ received Varivax. Of the remaining $30(18 \%)$ patients, the reason for not receiving the vaccine was not documented.

\section{The effect of IDC on vaccination rates}

Out of 68 Zostavax vaccine recipients, 67 had IDC and 1 did not (NIDC) (52\% vs. 3.7\%, $\mathrm{p}<.001)$. All 24 MMR recipients had IDC $(64.9 \%$ vs. $0 \%, p=0.0016)$. There was no significant difference between IDC and NIDC groups for varicella $(p=0.051)($ Table 2$)$.

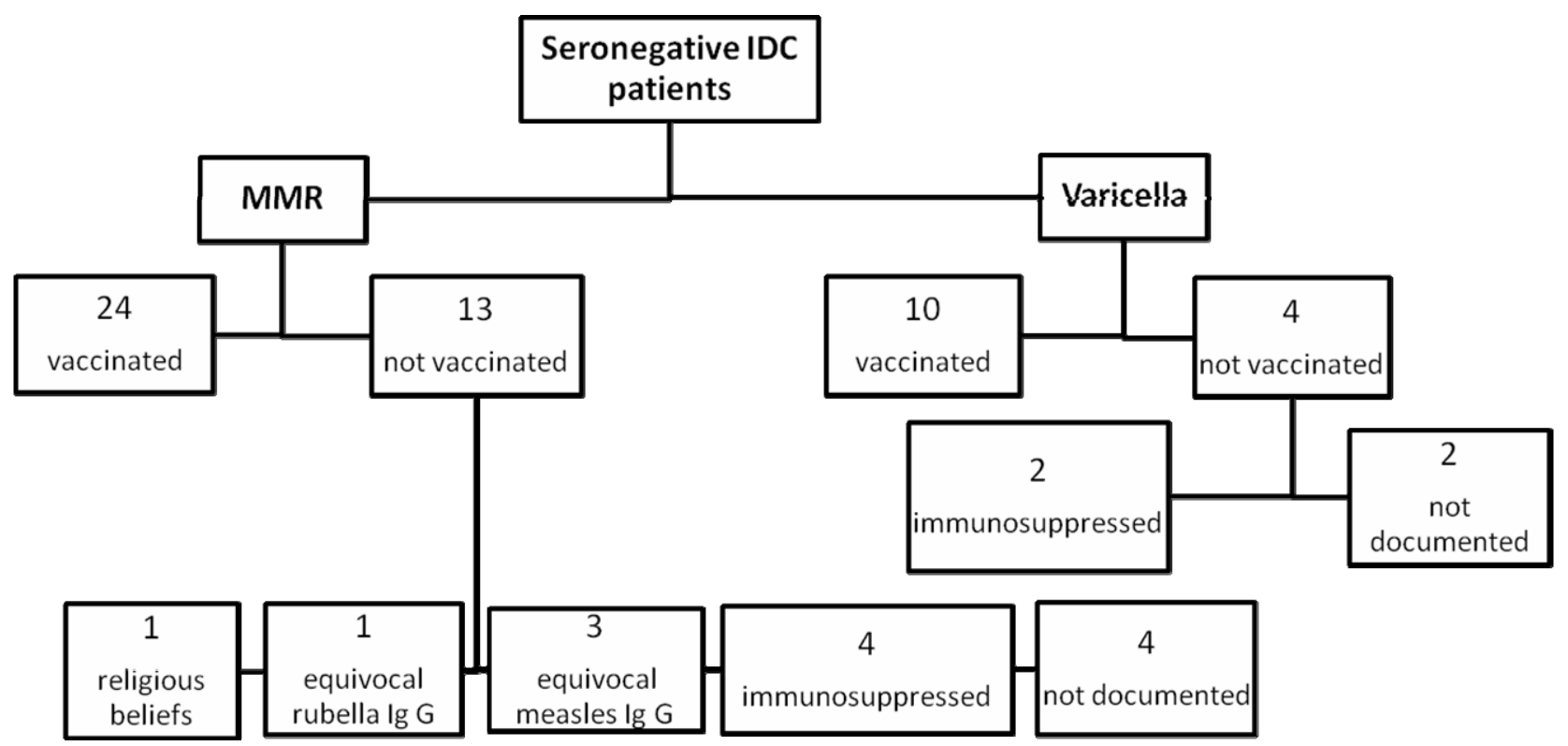

Figure 1. Flowchart shows the MMR and varicella vaccination status of seronegative IDC patients and the reasons for not being vaccinated.

Table 2

Vaccination rates

\begin{tabular}{|l|l|l|l|}
\hline & \multicolumn{1}{|c|}{ IDC (n= 235) } & \multicolumn{1}{|c|}{ NIDC (n= 47) } & \multicolumn{1}{c|}{ value } \\
\hline Zostavax given, $\mathbf{n}(\%)$ & $67(52)$ & $1(3.7)$ & $<.001$ \\
\hline MMR given, $\mathbf{n}(\%)$ & $24(64.9)$ & $0(0)$ & 0.0016 \\
\hline Varicella given, $\mathbf{n}(\%)$ & $10(71.4)$ & $0(0)$ & 0.051 \\
\hline
\end{tabular}

Values represent numbers and percentages. IDC $=$ Infectious Disease Consultation, NIDC $=$ No Infectious Disease Consultation. MMR $=$ Measles, mumps, rubella.

\section{DISCUSSION}

Post-transplant infections continue to be one of the major causes of mortality, morbidity, and graft rejections. Although mumps, measles, rubella, and varicella infections are unusual in the adult population, they are associated with a high morbidity [9]. Due to immunosuppression, SOT recipients demonstrate a great variety of signs and symptoms and may not have a classic presentation 
of those infections. Hence it is generally more difficult to diagnose and treat such conditions [10]. Previous studies demonstrated that post-transplant varicella infection can result in severe disease and even death $[9,11]$. Mortality due to varicella infection was not dependent on the time after transplantation; it could occur as early as post-transplant day 25 [11] or as late as 32 months [9]. Investigators of those studies emphasized that the mortality in allograft recipients could be preventable with just a simple step which is an appropriate pre-transplant vaccination schedule.

In our study, the majority of patients (83\%) received pre-transplant IDC. However, this high percentage does not match with the number of patients whose serologic status evaluation for vaccination was performed. Varicella was the only virus for which $100 \%$ of patient had serologic status assessed. In contrast, only $3 \%$ of patients had mumps serology performed. This huge gap can be partially explained by the presence of protocol-driven serologic screening for varicella and the absence of a similar protocol for MMR vaccination. A study from Kausz, A. et al. demonstrated lower infection rates and resultant reduced mortality with vaccination protocols followed during the pre-transplant period [12]. Baseline serology status determination is a useful tool to monitor the latent infection as well as to guide health care providers as to what vaccines should be given to this target population. Abad, C.L. et al. found that $60 \%$ of patients whose baseline varicella serology was available pre-transplant were seronegative [13]. In another study, all kidney allograft patients were found to have negative IgG for VZV [14]. The proportion of seronegative patients $(6 \%$ to $14 \%)$ in our study was not as high as the numbers in the previously conducted studies, yet it was not negligible. Given that being seronegative is not uncommon, individuals with negative $\operatorname{IgG}$ should be evaluated for effective vaccination administration.

Thirty-three percent to $45 \%$ of seronegative patients did not receive MMR or varicella vaccines. When we exclude immunocompromised patients and patients who are not in the vaccination age limits, $18 \%$ of IDC patients did not receive Zostavax before transplantation. The total vaccination rate among SOT group was low, despite the consensus and strong recommendations [15]. In 2019, the American Society of Transplantation provided a comprehensive guideline to immunize the adult SOT candidates and their households [7]. They pointed out the importance of early vaccination to reach full seroconversion in order to keep this special group of patients safe. Although vaccination is readily available, it is still underutilized in patients with chronic kidney disease (CKD), and there is a significant gap between guidelines and clinical practice $[15,16]$. Previous studies suggested immunizing CKD patients before transplantation or even before the onset of dialysis to reach higher rates of seroconversion [17]. Patients with advanced kidney disease, i.e., end-stage CKD, and receiving immunosuppressant therapy showed less sustained response after vaccination compared to healthy controls $[12,17]$. $\mathrm{CKD}$ is considered as an immunocompromised state as the function of immune cells is decreased or impaired [18]. Although the total antibody production remains the same, the amount of IgG produced is decreased in response to vaccination [16]. Furthermore, macrophages cannot properly function and produce immune mediated cytokines in the uremic environment [19]. The combination of those immune system abnormalities eventually causes lower seroconversion and a rapid decline in antibody levels $[19,20]$. Therefore, patients should be assessed for their serologic status at the earliest time, ideally during the initial assessment for the transplantation. Concomitantly, vaccines should be given to those who are not immunocompromised. After the transplantation, the antibody response significantly decreases due to use of immunosuppressive therapy $[4,5]$. Therefore, administration of live attenuated vaccine post transplantation increases concerns for unpredictable complications and safety. Overall, both in CKD and in the posttransplant period, vaccines become less effective and offer less protection. A study from Japan demonstrated that the 2016-2017 seasonal influenza vaccine was ineffective in kidney transplant patients [21]. Similarly, in another study, investigators revealed that the re-vaccination during the post-transplant period showed titer loss or failed to induce positive IgG for diphtheria, pertussis and hepatitis $\mathrm{B}$ in nearly $40 \%$ of their patients [22]. However, there are some controversial studies in the literature. One study in kidney transplant recipients, Kaul, A. et al. reached a conclusion that patients produced almost normal concentrations of antibodies after receiving the pneumococcal vaccine [14]. They thought that the reasoning behind this normal response was the better renal function after transplantation. Pittet et al. showed similar outcomes in the pediatric age group who received MMR [8]. The seroconversion rates reached up to $90 \%$ in three years after transplantation. However, more studies and larger sample sizes are needed to put those outcomes into routine guidelines, and incorporate them with clinical practice. 
It was previously shown that IDC has many benefits on mortality, hospital length of stay, and hospital expenses. IDC provides appropriate management recommendations for bloodstream infections such as MRSA [23, 24], candida [25, 26], pseudomonas [23], and enterococcus [27]. IDC gives healthcare workers a better perspective for the choice of antibiotic therapy together with a higher adherence to the guidelines, and subsequently, a better quality of care. The timing of IDC is also as important as its presence. Early IDC decreases the healthcare resource utilization and shortens the period of hospitalization [24, 28]. Additionally, one of the very crucial roles of IDC is its effect on the vaccination rates among the SOT candidates. Seronegative kidney transplant patients who have pre-transplant IDC were vaccinated more frequently compared to the NIDC group just like the outcomes we reached in heart, lung, and liver recipients [29]. Our findings in this study as well as our previous study assessing pre-transplant vaccination rates in heart, lung, and liver transplant recipients where we also identified that pre-transplant IDC improved vaccination rates are supported a previous study done by Kasper et al. [30].

Our study is single-centered and has a relatively small sample size. History of previous vaccine and infection recall percentages are low. This can be one of the limitations that we could not reach the ideal vaccination rates recommended by the guidelines.

\section{CONCLUSION}

Although AST guidelines for vaccination of kidney transplant recipients exist, serologic screening and vaccination rates are suboptimal. The pretransplant evaluation by ID is an undeniably important step both to implement protocol-driven serologic screening and to increase vaccination rates before the immunosuppressant therapy.

Introducere. Primitorii de transplant renal sunt la risc de a dezvolta complicații ale bolilor infecțioase ce pot fi prevenite prin vaccinare. Aceștia beneficiază de o evaluare completă pretransplant. Scopul studiului a fost de a evalua pacienții candidat pentru transplant renal evaluați serologic pentru rujeolă, oreion, rubeolă (MMR) şi varicelă. Secundar a fost evaluat dacă consultul de boli infecțioase inaintea transplantului (IDC) a îmbunătățit ratele vaccinale.

Metode. Au fost analizate fișele a 282 pacienți candidat pentru transplant renal, născuți după 1957. Pacienții au fost evaluați la clinica Mayo din Florida intre ianuarie 2015 și decembrie 2017. Statusul serologic și ratele vaccinale au fost analizate în cele două grupuri de pacienți create pe baza prezenței IDC sau absenței acesteia (NIDC).

Rezultate. 235 din 282 pacienți (83\%) au primit IDC pretansplant. Nivelurile anticorpilor anti varicelă IgG au fost evaluate la toți cei 235 de pacienți din grupul IDC. In grupul IDC serologii IgG au fost efectuate la oreion la 7 pacienți (3\%), la rubeolă la 143 pacienți (61\%) și la rujeolă la 144 de pacienți (61\%). Din cei 44 pacienți negativi la oricare MMR, 24 (55\%) au fost vaccinați. 10 din 15 pacienți seronegativi la varicelă au fost vaccinați. Zostavax nu a fost administrat la $18 \%$ din pacienții din grupul IDC. Zostavax și MMR au fost administrate mai frecvent in grupul IDC decât în grupul NIDC $(p<.001$ și $p=0.0016)$.

Concluzii. Deși majoritatea pacienților au avut IDC, ratele de screening pentru MMR au fost mai mici decât cele la varicelă. Un protocol bazat pe screeningul serologic similar cu cel pentru VZV este necesar și pentru MMR. IDC pretransplant crește ratele de vaccinare.

Correspondence to: Lisa M. Brumble, M.D. Department of Infectious Diseases, Mayo Clinic 4500 San Pablo Road, Jacksonville, FL 32224

Email: brumble.lisa@mayo.edu

Phone: 904-953-2419

Acknowledgements: None.

Conflict of interest disclosure: The authors of this manuscript have no conflicts of interest to disclose. 
Author contributions: All authors decided to study concept and design, discussed the data results, contributed to drafting of the manuscript and approved the final version for submission. L.M.B. is the guarantor of the paper.

Funding: None.

Abbreviations: MMR: Measles, mumps, rubella; VZV: Varicella; IDC: Infectious Diseases Consultation; NIDC: No Infectious Diseases Consultation; SOT: Solid Organ Transplant.

\section{REFERENCES}

1. UNITED NETWORK FOR ORGAN SHARING. Organ donation again sets record in 2019. UNOS 2020. https://unos.org/news/ organ-donation-sets-record-in-2019/.

2. SARAN R, ROBINSON B, ABBOTT KC, AGODOA LYC, BRAGG-GRESHAM J, BALKRISHNAN R, et al. US Renal Data System 2018 Annual Data Report: Epidemiology of Kidney Disease in the United States. American Journal of Kidney Diseases 2019; 73:A7-8.

3. SESTER M, GÄRTNER BC, GIRNDT M, SESTER U. Vaccination of the solid organ transplant recipient. Transplantation Reviews 2008; 22:274-84

4. GANGAPPA S, KOKKO KE, CARLSON LM, GOURLEY T, NEWELL KA, PEARSON TC, et al. Immune responsiveness and protective immunity after transplantation. Transplant International 2008; 21:293-303.

5. VAN KESSEL DA, HOFFMAN TW, VAN VELZEN-BLAD H, VAN DE GRAAF EA, GRUTTERS JC, RIJKERS GT. Immune status assessment in adult lung transplant candidates. Transplant Immunology 2017; 40:31-4.

6. LOPEZ A, MARIETTE X, BACHELEZ H, BELOT A, BONNOTTE B, HACHULLA E, et al. Vaccination recommendations for the adult immunosuppressed patient: A systematic review and comprehensive field synopsis. Journal of Autoimmunity 2017; 80:10-27.

7. DANZINGER-ISAKOV L, KUMAR D. Guidelines for Vaccination of Solid Organ Transplant Candidates and Recipients. American Journal of Transplantation 2009; 9:S258-62.

8. PITTET LF, VEROLET CM, MCLIN VA, WILDHABER BE, RODRIGUEZ M, CHERPILLOD P, et al. Multimodal safety assessment of measles-mumps-rubella vaccination after pediatric liver transplantation. American Journal of Transplantation 2018; 19:844-54.

9. RODRIGUEZ-MORENO A, SANCHEZ-FRUCTUOSO AI, CALVO N, RIDAO N, CONESA J, MARQUES M, et al. Varicella Infection in Adult Renal Allograft Recipients: Experience at One Center. Transplantation Proceedings 2006; 38:2416-8.

10. GREENDYKE WG, PEREIRA MR. Infectious Complications and Vaccinations in the Posttransplant Population. Medical Clinics of North America 2016; 100:587-98.

11. DEPLEDGE DP, BROWN J, MACANOVIC J, UNDERHILL G, BREUER J. Viral Genome Sequencing Proves Nosocomial Transmission of Fatal Varicella. Journal of Infectious Diseases 2016; 214:1399-402.

12. KAUSZ A, PAHARI D. The Value of Vaccination in Chronic Kidney Disease. Seminars in Dialysis 2004; 17:9-11.

13. ABAD CL, RAZONABLE RR. $\alpha$ Herpes Virus Infections Among Renal Transplant Recipients. Seminars in Nephrology 2016; $36: 344-50$.

14. KAUL A, SHARMA RK, BHADHURIA D, GUPTA A, PRASAD N. Chickenpox infection after renal transplantation. Clinical Kidney Journal 2012; 5:203-6.

15. LEE DH, BOYLE SM, MALAT G, SHARMA A, BIAS T, DOYLE AM. Low rates of vaccination in listed kidney transplant candidates. Transplant Infectious Disease 2016; 18:155-9.

16. CAMARGO LF, LOTHER AM, MAZZALI M, STUCCHI RSB. Immunization in end stage renal disease: The perception of waiting list patients. Transplant Infectious Disease 2018; 20:e12831.

17. KRUEGER KM, ISON MG, GHOSSEIN C. Practical Guide to Vaccination in All Stages of CKD, Including Patients Treated by Dialysis or Kidney Transplantation. American Journal of Kidney Diseases 2020; 75:417-25.

18. CHATENOUD L, HERBELIN A, BEAURAIN G, DESCAMPS-LATSCHA B. Immune Deficiency of the Uremic Patient. In: Grünfeld J-P, editor. Advances in Nephrology from the Necker Hospital, Chicago: Year Book Medical Publ; 1990, p. 259-74.

19. JOHNSON DW, FLEMING SJ. The Use of Vaccines in Renal Failure. Clinical Pharmacokinetics 1992; 22:434-46.

20. FUCHSHUBER A, KUHNEMUND O, KEUTH B, LUTTICKEN R, MICHALK D, QUERFELD U. Pneumococcal vaccine in children and young adults with chronic renal disease. Nephrology Dialysis Transplantation 1996; 11:468-73.

21. TSUJIMURA K, OTA M, CHINEN K, NAGAYAMA K, OROKU M, SHIOHIRA Y, et al. Effect of Influenza Vaccine in Patients With Kidney Transplant. Transplantation Proceedings 2018; 50:2443-6.

22. HÖCKER B, AGUILAR M, SCHNITZLER P, PAPE L, BALD M, KÖNIG J, et al. Vaccination titres pre-and post-transplant in paediatric renal transplant recipients and the impact of immunosuppressive therapy. Pediatric Nephrology 2018; 33:897-910.

23. CHESDACHAI S, KLINE S, HELMIN D, RAJASINGHAM R. The Effect of Infectious Diseases Consultation on Mortality in Hospitalized Patients With Methicillin-Resistant Staphylococcus aureus, Candida, and Pseudomonas Bloodstream Infections. Open Forum Infectious Diseases 2020; 7.

24. KAWASUJI H, SAKAMAKI I, KAWAMURA T, UENO A, MIYAJIMA Y, MATSUMOTO K, et al. Proactive infectious disease consultation at the time of blood culture collection is associated with decreased mortality in patients with methicillin-resistant Staphylococcus aureus bacteremia: A retrospective cohort study. Journal of Infection and Chemotherapy 2020; 26:588-95.

25. LAGROU K, VAN WIJNGAERDEN E. Infectious disease consultation lowers candidaemia mortality. The Lancet Infectious Diseases 2019; 19:1270-2. 
26. MOHR A, SIMON M, JOHA T, HANSES F, SALZBERGER B, HITZENBICHLER F. Epidemiology of candidemia and impact of infectious disease consultation on survival and care. Infection 2020; 48:275-84. https://doi.org/10.1007/s15010-02001393-9.

27. LEE RA, VO DT, ZURKO JC, GRIFFIN RL, RODRIGUEZ JM, CAMINS BC. Infectious Diseases Consultation Is Associated With Decreased Mortality in Enterococcal Bloodstream Infections. Open Forum Infectious Diseases 2020; 7. https://doi.org/ 10.1093/ofid/ofaa064.

28. HAMANDI B, HUSAIN S, HUMAR A, PAPADIMITROPOULOS EA. Impact of Infectious Disease Consultation on the Clinical and Economic Outcomes of Solid Organ Transplant Recipients Admitted for Infectious Complications. Clinical Infectious Diseases 2014; 59:1074-82. https://doi.org/10.1093/cid/ciu522.

29. SECKIN ZI, BRUMBLE LM, LIBERTIN CR. Serologic screening and infectious disease consultation (IDC): Indicated in heart, lung, liver (HLL) solid organ transplants (SOT) for measles, mumps, rubella, and varicella. Transplant Infectious Disease 2019; 22. https://doi.org/10.1111/tid.13202.

30. KASPER AK, PALLOTTA AM, KOVACS CS, SPINNER ML. Infectious diseases consult improves vaccination adherence in kidney transplant candidates. Vaccine 2018; 36:5112-5. https://doi.org/10.1016/j.vaccine.2018.06.058. 